\title{
Influence of atmospheric teleconnections and Upper Circumpolar Deep Water on phytoplankton biomass around Elephant Island, Antarctica
}

\author{
Christian S. Reiss ${ }^{1, *}$, Christopher D. Hewes ${ }^{2}$, Osmund Holm-Hansen ${ }^{2}$ \\ ${ }^{1}$ Antarctic Ecosystem Research Division, NOAA Fisheries, Southwest Fisheries Science Center, La Jolla, California 92037, USA \\ ${ }^{2}$ Polar Research Program, Scripps Institution of Oceanography, La Jolla, California 92093-0202, USA
}

\begin{abstract}
Using 18 years of hydrographic data collected during austral summer from 1990 to 2007 , we examined the association between atmospheric teleconnections, seasonal mean water column properties and phytoplankton biomass around Elephant Island (EI), Antarctica. We developed an index of the extent of Upper Circumpolar Deep Water (UCDW) in the EI region, defined as the mean temperature at the $27.6 \mathrm{~kg} \mathrm{~m}^{-3}\left(\sigma_{\mathrm{t}}\right)$ isopycnal. We found a positive correlation $(\mathrm{r}=0.60 ; \mathrm{p}<0.001)$ between this index of UCDW extent and the magnitude of the seasonal Southern Oscillation Index (SOI). No linear secular trend was observed in temperature at the $27.6 \sigma_{\mathrm{t}}$ isopycnal, but significant interannual patterns of variability were observed and polynomial regression suggested that potential long-term decadal (or longer) scale variability was captured. Mean Upper Mixed Layer (UML) chlorophyll a ( $\mathrm{chl}$ a) concentration was not correlated with this UCDW index, but was positively correlated with the strength of the SOI. Mean integrated chl a biomass of the UML was positively correlated $(r=0.88 ; p<0.001)$ with the mean UML chl a concentration. Stepwise regression showed that variability in mean UML chl a concentration over the 18-yr time series was more strongly correlated with UML temperature than UML depth. Although the correlations were weak, these results suggest that the deepening of the UML during El Niño conditions was likely the result of colder temperatures within the UML that limited bloom conditions over this 18-yr time series, with the opposite pattern during La Niña.
\end{abstract}

KEY WORDS: Climate change · Upper Circumpolar Deep Water · Antarctic · South Shetland Islands · Phytoplankton $\cdot \mathrm{El}$ Niño $\cdot \mathrm{ENSO} \cdot \mathrm{SOI} \cdot \mathrm{Sea}$ ice

Resale or republication not permitted without written consent of the publisher

\section{INTRODUCTION}

The Antarctic Peninsula and adjacent regions of the southwestern Atlantic Ocean have experienced significant environmental change over the last 50 yr. Among these are a warming of the mean annual air temperature by $0.5^{\circ} \mathrm{C}$ per decade (Turner et al. 2005), changes in sea ice extent and duration (Liu et al. 2002, Stammerjohn et al. 2003), and increases in water temperature (Gille 2002). Many of these changes have been linked to variability in global atmospheric climate patterns (White \& Peterson 1996, White \& Annis 2004), including the El Niño-Southern Oscillation (ENSO;
Stammerjohn \& Smith 1997, Kwok \& Comiso 2002) and the Southern Annular Mode (SAM; Meredith \& King 2005). This climatic variability could affect the strength of the Antarctic Circumpolar Current (ACC; Meredith et al. 2004), influencing primary productivity of the Southern Ocean (Pollard et al. 2006).

Upper Circumpolar Deep Water (UCDW) is a warm, oxygen poor and relatively nutrient rich (Sievers \& Nowlin 1984, Holm-Hansen et al. 1997, Hewes et al. 2008) water mass that is present below the Winter Water remnant of Antarctic Surface Water (AASW) within the ACC. South of the Polar Front, it is found at depths $>600 \mathrm{~m}$ before shoaling to between 150 and 
$300 \mathrm{~m}$ depth near the continental margin (Orsi et al. 1995, 2005, Pollard et al. 2002) and defines the southern boundary of the ACC (Orsi et al. 1995). UCDW upwells in response to geostrophy and may control the out-cropping of nutrients and trace metals (including Fe) into surface waters, thereby enhancing phytoplankton productivity (Tynan 1998, Pollard et al. 2002, 2006, Hiscock et al. 2003). Along the shelf of the West Antarctic Peninsula (WAP), the influence of UCDW is great and may affect both primary production and phytoplankton community structure (Prézelin et al. $2000,2004)$, as well as the heat balance on the continental shelf in that area (Klinck 1998). Paleo-oceanographic data show increased primary production is associated with warm waters in the WAP area and the Scotia Sea (Shevenell \& Kennett 2004, Sachs \& Anderson 2005) during warmer periods and when UCDW influence is thought to have been large. As such, variability in the strength of the ACC may impact upwelling and, therefore, may affect the input of phytoplankton biomass-controlling trace metals along Antarctic coastal environments (over a variety of time scales) by modifying the extent and influence of UCDW in this region.

Resolution of the importance of UCDW to dynamical and biological budgets in the more productive areas of the Southern Ocean is critical given the dramatic secular changes in the Antarctic Peninsula region over the last 50 yr (Turner et al. 2005), the influence of atmospheric quasi-periodic forcing (White \& Peterson 1996, Meredith \& King 2005), and links to global event scale processes (Turner 2004). Here, we examine the inter-annual and decadal extent of UCDW in continental shelf waters around Elephant Island (EI), Antarctica, using 18 yr of hydrographic data collected as part of the US Antarctic Marine Living Resources Program (AMLR; Lipsky 2007).

The southern boundary of the ACC (Orsi et al. 1995, Pollard et al. 2002) is located within the AMLR survey area and its latitudinal displacement can be tracked in hydrographic data (Loeb et al. 2008). We developed an index of UCDW extent (the mean temperature at the $27.6 \sigma_{\mathrm{t}}$ isopycnal) in the EI area of the Antarctic Peninsula and examined how sea ice and atmospheric variability may influence it (using 2 additional indices). The first is the Southern Oscillation Index (SOI; NOAA Climate Data Center, Boulder, CO, USA) defined as the sea level anomaly between Darwin
(Australia) and Tahiti. It represents the principal atmospheric condition in the southwestern Pacific basin. The second is a sea ice area index (Hewitt et al. 2003) defined as the areal distribution of the $15 \%$ ice concentration, which has been correlated with the recruitment success of Antarctic krill (Loeb et al. 1997, Hewitt et al. 2003). We investigated how these 2 indices correlate with surface water properties of the area and how they may be used to interpret patterns of interannual variability in phytoplankton biomass (Holm-Hansen et al. 1997, HolmHansen \& Hewes 2004, Hewes et al. 2008). These relationships are then used to determine and describe the potential mechanisms that control phytoplankton productivity for this area over the 18-yr time period.

\section{MATERIALS AND METHODS}

The US AMLR program has collected hydrographic and chlorophyll a (chl a) data in support of Antarctic krill biomass surveys since 1990. In general, 2 summer surveys (January to February and February to March) are conducted annually in the vicinity of EI (Fig. 1, bold box). From 1991 to 1996, ca. 72 stations were occupied

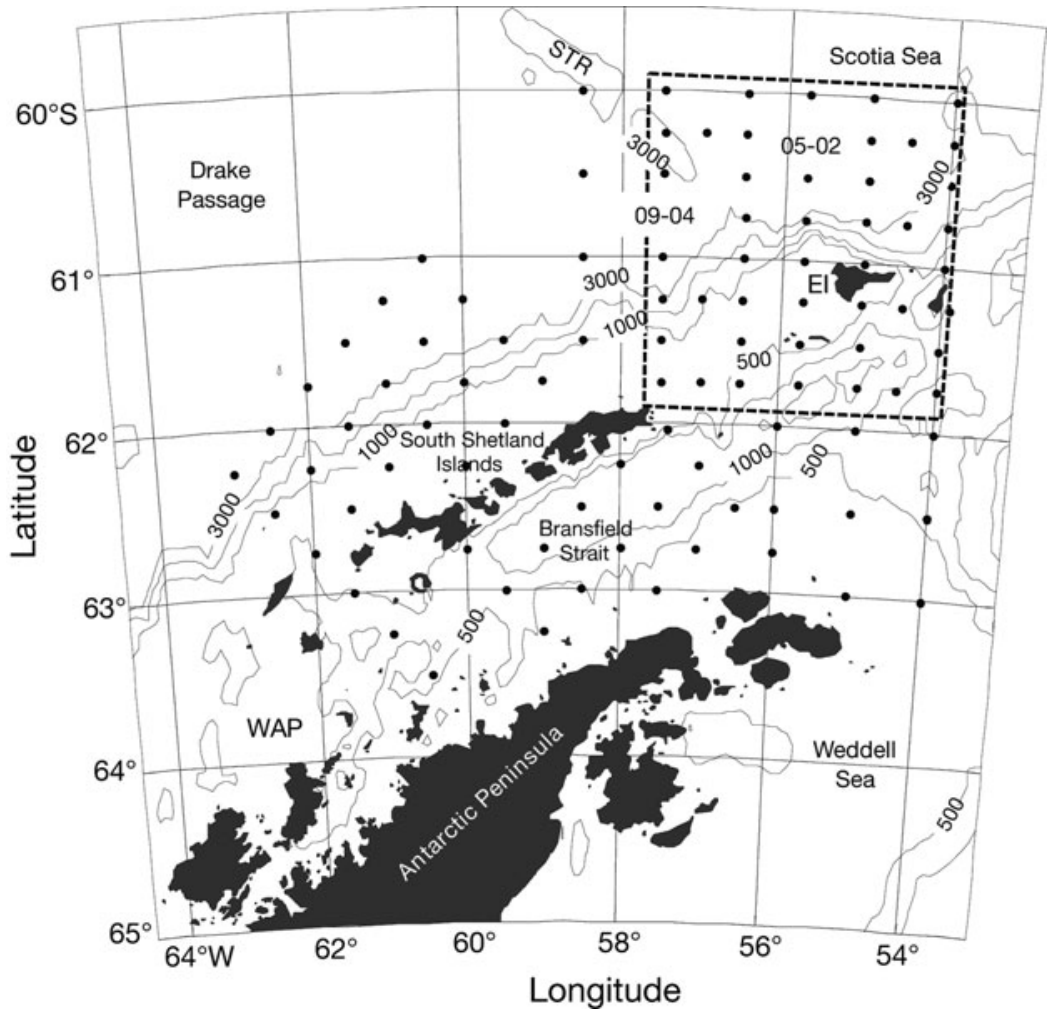

Fig. 1. South Shetland and Elephant Island (EI) regions surveyed by the US Antarctic Marine Living Resources (AMLR) program between 1990 and 2007. Filled circles represent current sampling locations; the heavy box around the EI area encloses the stations used in the analyses. WAP: West Antarctic Peninsula; STR: Shackleton Transverse Ridge. Stns 09-04 and 05-02 are labeled on the chart. The thin continuous lines show the 500,1000, 2000 and $3000 \mathrm{~m}$ isobaths 
during each leg of each survey. Beginning in 1996, several stations from 2 transects were discontinued. Additionally, since 1996, the survey area was increased to include the Bransfield Strait and the shelf region seaward of the South Shetland Islands (not used in our analysis). In several years, only a single survey was conducted during the January to February (1997, 2006-2007) or February to March (2000) time periods. Thus, areal effort around EI was similar among years, although the number of stations occupied per survey varied from 48 for complete single legs in 2006 to 144 stations for 2 legs in 1994. Differences relate to changing effort within the survey area, the number of legs, and weather days. In all, 1790 stations were occupied over the 18 yr of surveys in the EI area.

At each station, water column data were collected with a Sea-Bird SBE-9/11+ CTD/carousel water sampler equipped with eleven 101 Niskin sampling bottles. In general, CTD casts were limited to a depth of $750 \mathrm{~m}$, or $5 \mathrm{~m}$ above the sea bottom when shallower than $750 \mathrm{~m}$, and water samples were collected at 11 standard depths $(750,200,100,75,50,40,30,20,15,10$ and $5 \mathrm{~m}$ ). The CTD was calibrated by Sea-Bird before and after every cruise. In general, pre- and post-cruise calibrations were only a few months apart because of the short durations of the field seasons. Further, salinity samples from each station were used to check calibration of the CTD using a Guildline Portasal and standard seawater.

Upper mixed layer depth determination. Depth of the Upper Mixed Layer (UML) was determined from the CTD data and calculated as the depth at which potential density $\left(\sigma_{\mathrm{t}}\right)$ differed by $0.05 \mathrm{~kg} \mathrm{~m}^{-3}$ from the mean potential density measured between 5 and $10 \mathrm{~m}$ depth.

Nutrient and chlorophyll a determinations. At selected stations and depths and during several years (1991-1995, 1997-1999, 2004-2006), water was sampled from the CTD and collected in acid-washed $112 \mathrm{ml}$ polypropylene bottles and immediately frozen for nutrient analysis. These frozen seawater samples were analyzed by auto-analyzer for nitrate, phosphate, and silicate concentrations (Atlas et al. 1971). Samples were usually processed within 1 to 3 mo after the field season.

The chl a concentration $\left(\mathrm{mg} \mathrm{m}^{-3}\right)$ at each target depth over the upper $200 \mathrm{~m}$ of the water column was determined by fluorometric methods (Holm-Hansen et al. 1965, Holm-Hansen \& Riemann 1978). Fluorescence was measured using either a Turner Designs 10AU (1990 to 1996) or TD 700 (1997 to 2007) fluorometer, calibrated using a solution of pure chl a (Sigma), the concentration of which was determined spectrophotometrically (Jeffrey \& Humphery 1975). Stability of the fluorometer was verified daily by use of various refer- ence standards. The mean concentrations (mg chl a $\mathrm{m}^{-3}$ ) and integrated biomasses ( $\mathrm{mg} \mathrm{chl} a \mathrm{~m}^{-2}$ ) in the UML across the EI region were calculated for each year.

Atmospheric indices. Monthly values of the SOI were obtained from archives maintained at www.cdc. noaa.gov/Climateindices/List. We averaged monthly data from December, prior to the field season, through March (e.g. December 1996, January to March 1997) to provide seasonal indices under the assumption that the importance of UCDW in the EI shelf region would reflect forcing in the current year. The sea ice index was developed for the South Shetland Island area building on the work of Hewitt et al. (2003). Daily Special Sensor Microwave/Imager (SSM/I) data (ftp:// sidads.colorado.edu/pub/datasets/passivemicrowave/ polarstereo/data/seaice/ssmi/) were used to develop the index of annual sea ice extent (15\% sea ice concentration) and persistence, covering the region from 58 to $65^{\circ} \mathrm{S}$ and from 55 to $65^{\circ} \mathrm{W}$.

Statistical analysis. Means of yearly (combined across legs and stations) hydrographic data were used to assess associations and relationships between and among atmospheric indices, our index of UCDW extent (water temperature at the $27.6 \sigma_{t}$ isopycnal) and other hydrographic parameters. Preliminary analysis of the data showed no significant lag-1 correlations over time when de-meaned and linearly de-trended data were examined. Ordinary Least Squares (OLS) regression was therefore used to examine temporal trends in means. Means of the dependent variable were weighted by the inverse of the variance to account for the differing sampling effort among years. Secondorder interactions were allowed to account for the potential for low frequency variability when secular trends were not apparent. When necessary, we used forward stepwise regression to choose among significant variables when temporal patterns were examined. Time and depth contour plots of water column temperature at 2 stations (Fig. 1), west and east of the Shackleton Transverse Ridge (STR), were also used to examine temporal trends in water properties (US AMLR Stns 09-04 and 05-02, respectively.)

\section{RESULTS}

\section{Trends and patterns in water column properties}

Mean water temperature and salinity at the $27.6 \sigma_{t}$ isopycnal exhibited considerable inter-annual variability between 1990 and 2007 (Fig. 2a,b). For example, 1992 and 1998 were coolest, while 2002 was warmest. Salinity at the $27.6 \sigma_{\mathrm{t}}$ depth varied in a similar manner, with 1992 and 1998 being least saline and 2002 being 

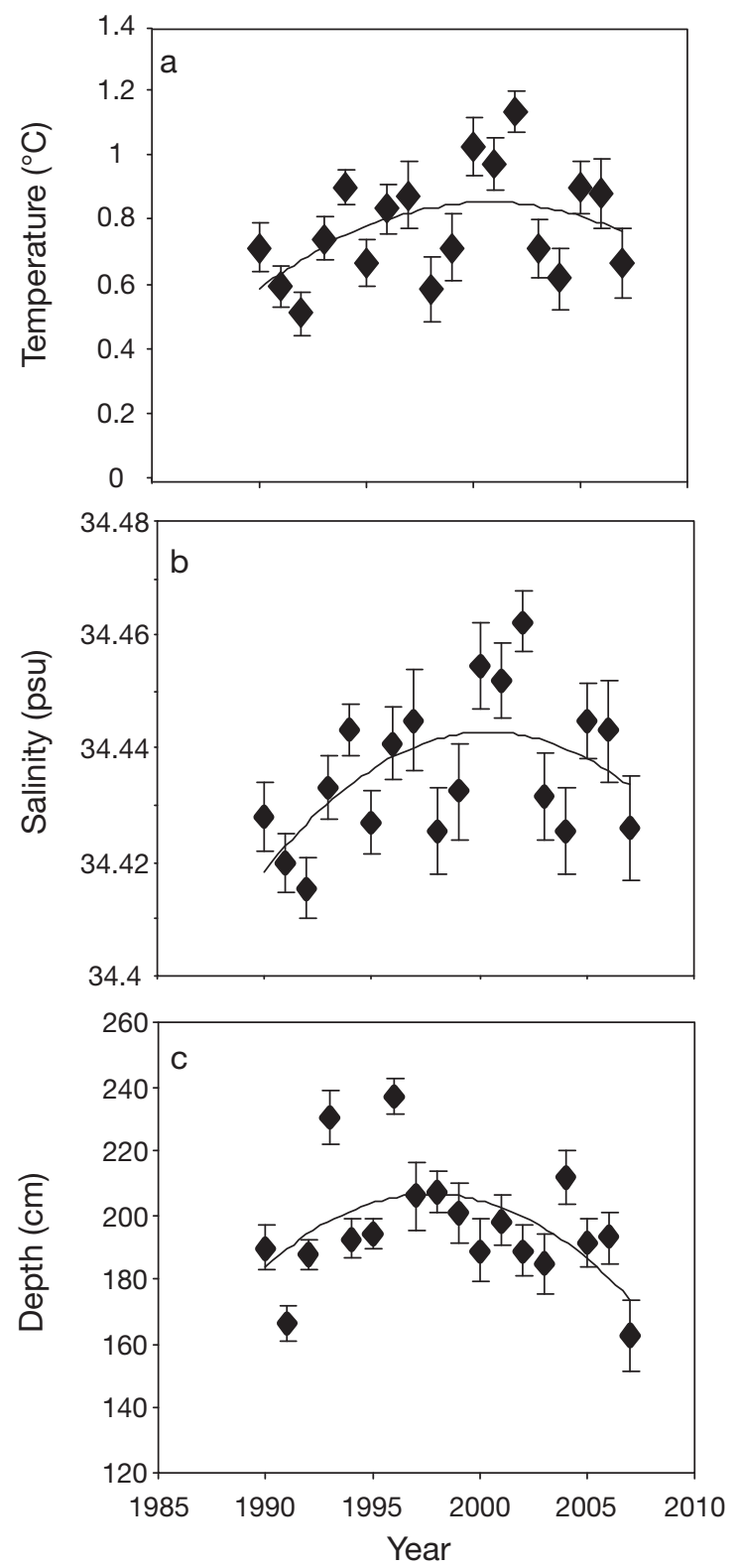

Fig. 2. Temporal patterns for mean $( \pm \mathrm{SE}) 27.6 \sigma_{\mathrm{t}}$ isopycnal (a) temperature, (b) salinity, and (c) depth. Polynomial least squares fits are used to show long term variability in these water column properties

most saline; however, the variability in the salinity at the $27.6 \sigma_{\mathrm{t}}$ isopycnal varied by only about 0.04 over the time series. Despite the rather narrow salinity range, the mean temperature and salinity at the $27.6 \sigma_{\mathrm{t}}$ depth were positively correlated $(\mathrm{r}=0.88, \mathrm{p}<0.01)$ and periods of relatively high temperature and high salinity at the $27.6 \sigma_{\mathrm{t}}$ isopycnal (averaged across the EI region) are indicative of a strong UCDW presence.

The depth of the 27.6 $\sigma_{\mathrm{t}}$ isopycnal (Fig. 2c) also varied over the time series. Between 1990 and 1996, the depth of this isopycnal varied from about 160 to $200 \mathrm{~m}$ before shoaling to $\sim 180 \mathrm{~m}$ through 2005 . The depth of the $27.6 \sigma_{\mathrm{t}}$ isopycnal was greatest in 1993 and 1996, and shallowest in 2007. Among these years, depth of the $27.6 \sigma_{\mathrm{t}}$ isopycnal varied by more than $70 \mathrm{~m}$, suggesting considerable shoaling during some years of the time series.

Although there was considerable interannual variability in the temperature, salinity and depth of the $27.6 \sigma_{t}$ isopycnal time series, we fit second order polynomial regressions to each of the time series to examine whether interannual changes might also reflect long-term trends. Temperature and depth of the $27.6 \sigma_{t}$ isopycnal exhibited weak $(0.05<\mathrm{p}<0.1)$ trends over the time series, while the salinity at the $27.6 \sigma_{\mathrm{t}}$ isopycnal exhibited a significant temporal pattern $(\mathrm{p}<0.02)$. The inter-annual variability in subsurface water properties, in particular the temperature and the depth of the $27.6 \sigma_{\mathrm{t}}$ isopycnal, was also visible in contour plots (Fig. 3) for 2 stations west and east of the Shackleton Transverse Ridge (STR). Within the surface layer, water temperature varied from 2 to $\sim 4^{\circ} \mathrm{C}$, and these warm periods were associated with shoaling of the $27.6 \sigma_{t}$ isopycnal (Fig. 2). A subsurface temperature minimum $\left(<0.5^{\circ} \mathrm{C}\right)$ representing the Winter Water (WW) remnant was also present over the time series at a depth of 70 to $100 \mathrm{~m}$ (Fig. 3). West of the STR and below the WW remnant, the water was slightly cooler $\left(<2^{\circ} \mathrm{C}\right)$ from 1990 to about 1996 (Fig. 3a) than during the late 1990s, when it was $>2{ }^{\circ} \mathrm{C}$. After about 2000, temperatures below the WW remnant were more variable. East of the STR (Fig. 3b), the water column is hydrographically more complex; consequently, temperature was more variable and the depth of the $27.6 \sigma_{t}$ isopycnal was shallower, but was generally similar to the pattern west of the STR (Fig. 3a).

Within the UML, a different temporal pattern emerged (Fig. 4) compared to the temporal features at the $27.6 \sigma_{\mathrm{t}}$ isopycnal (Fig. 2). Although depth and temperature of the UML were inversely correlated over the time series (Figs. 4a,b), neither exhibited any secular trends or any significant long-term oscillations that might be resolved using a polynomial regression. The shallowest UML depth and highest UML temperatures occurred during 2006. The salinity in the UML (Fig. 4c) was elevated $(\sim 34)$ during the early 1990s and then declined throughout the mid-1990s (to 33.8 in 1995) before increasing again until the early 2000s. It then remained fairly constant until 2007 when salinity increased. UML depth and UML temperature were highly correlated ( $\mathrm{r}>-0.75$; $\mathrm{p}<0.001$; Fig. 4b), while UML depth and UML salinity were not $(\mathrm{r}=0.42 ; \mathrm{p}>$ 0.07; not shown). This pattern suggests that interannual variability in the depth of the UML was mostly influenced by temperature variability, probably through surficial heat flux. 

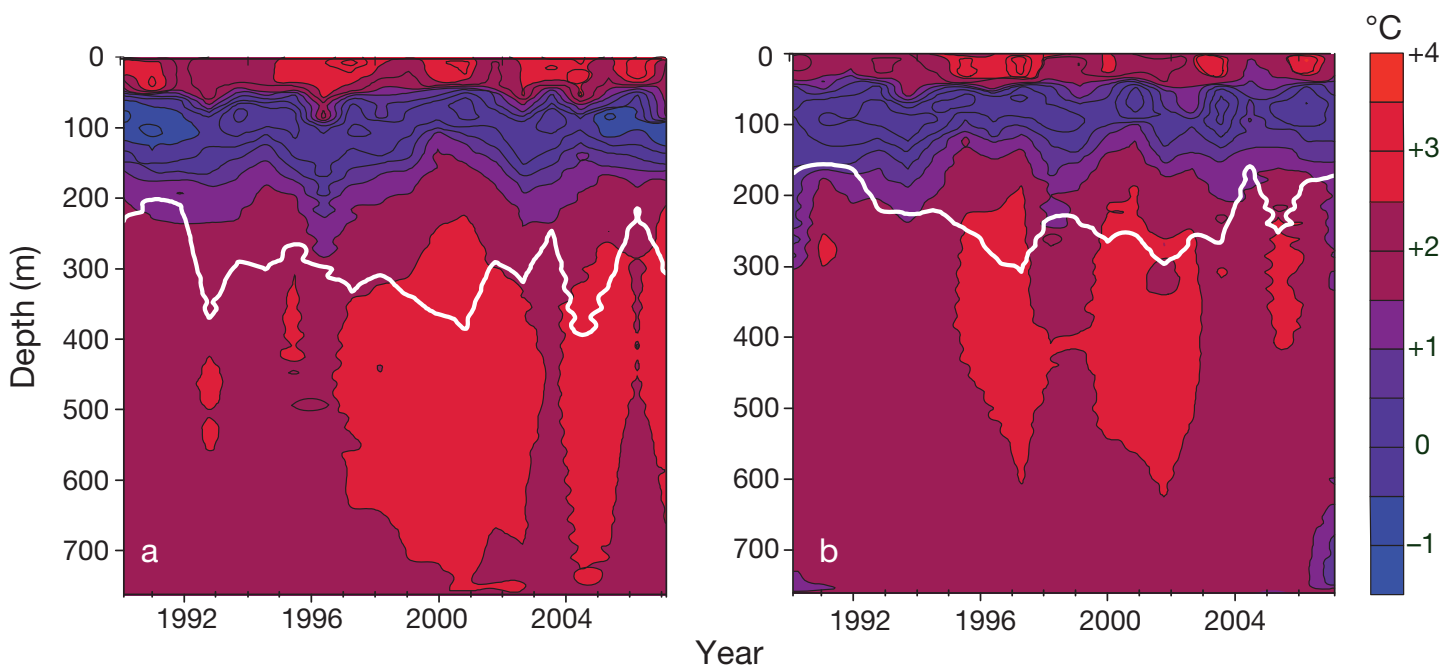

Fig. 3. Time series contour plots of temperature $\left({ }^{\circ} \mathrm{C}\right.$ ) versus depth over time from 1990 to 2007 at (a) Stn 09-04 located northwest of Elephant Island (EI) and west of the Shackleton Transverse Ridge (STR) and (b) Stn 05-02 located north of EI and east of the STR. Bold white line represents depth of the $27.6 \sigma_{\mathrm{t}}$ isopycnal. Color contours are in increments of $0.5^{\circ} \mathrm{C}$ from $-1.5^{\circ} \mathrm{C}$ (blue) to $+4^{\circ} \mathrm{C}(\mathrm{red})$

Some surface water properties were significantly correlated with depth of the $27.6 \sigma_{\mathrm{t}}$ isopycnal. For example, salinity in the UML was negatively correlated with the depth of the 27.6 isopycnal (Fig. 5a; $r=$ -0.74 ; p $<0.001)$, with lowest salinities $(\sim 33.9)$ associated with the deepest occurrence of the $27.6 \sigma_{\mathrm{t}}$ isopycnal. While temperature exhibited an opposite trend, the correlation was not significant (Fig. 5b). However, this is not unexpected, as the heat flux in the surface layer will influence the temperature of the surface waters across the EI region independent of salinity. The pattern of the depth of the $27.6 \sigma_{t}$ isopycnal (Fig. 2c) corresponded with the lowest UML salinities (Fig. 4c) of the time series (mid 1990s). Given these patterns, it seems likely that high salinity, but cool water was present in the UML when the $27.6 \sigma_{\mathrm{t}}$ isopycnal was shallow.

\section{Relationship of hydrography to phytoplankton biomass}

Mean UML chl a concentration and UML integrated chl a biomass varied considerably over the 18-yr time series (Fig. 6a). The highest chl a concentrations $\left(>1.5 \mathrm{mg} \mathrm{m}^{-3}\right.$ ) were observed in 1995 and 2006, while the lowest concentrations $\left(\leq 0.5 \mathrm{mg} \mathrm{m}^{-3}\right)$ were observed in 1992, 1998, and 2001. Similar temporal patterns were also found in UML integrated chl a biomass, with maxima occurring in 1995, 1999 and 2006, and minima occurring in 1993, 1998 and 2001. UML integrated chl a biomass was highly positively correlated $(r>0.88$; $\mathrm{p}<0.001)$ with the mean UML chl a concentration. The positive relationship between these 2 estimates of phytoplankton abundance indicates that mean UML chl a concentration is appropriate for analyzing relationships between the environment and phytoplankton abundance.

Phytoplankton concentration was neither correlated with the depth or temperature at the $27.6 \sigma_{\mathrm{t}}$ isopycnal, nor with UML salinity. Instead, chl a concentration in the UML was positively correlated with UML temperature (Fig. $6 b_{;} r=0.67 ; p<0.01$ ), and exhibited a negative trend with UML depth (Fig. 6c; $r=0.5 ; \mathrm{p}<0.05$ ). The high chl a concentration measured in 1995 was not associated with similar conditions of temperature or depth of the UML. Stepwise, inverse-variance weighted regression of UML depth and UML temperature versus UML chl a concentration revealed that only UML temperature $(\mathrm{r}=0.57 ; \mathrm{p}<0.01)$ was important in explaining chl a concentration over the 18 -yr time period.

\section{Atmospheric teleconnections}

Mean temperature (Fig. 7a) and salinity (not shown) at the $27.6 \sigma_{\mathrm{t}}$ isopycnal were positively correlated with the magnitude of the SOI $(\mathrm{r}>0.55 ; \mathrm{p}<0.02$ for each), suggesting a decrease in high temperature, high salinity water characteristic of UCDW during ENSO periods. The residuals of a polynomial regression of the $27.6 \sigma_{\mathrm{t}}$ isopycnal temperature time series (to account for potential low frequency variability; Fig. 2,3) were still weakly correlated with the SOI $(\mathrm{r}=0.48 ; \mathrm{p}<0.08)$. A weak positive association between UML temperature and the SOI was also found $(\mathrm{r}=0.42 ; \mathrm{p}<0.08)$, suggesting that the surface water was slightly cooler 

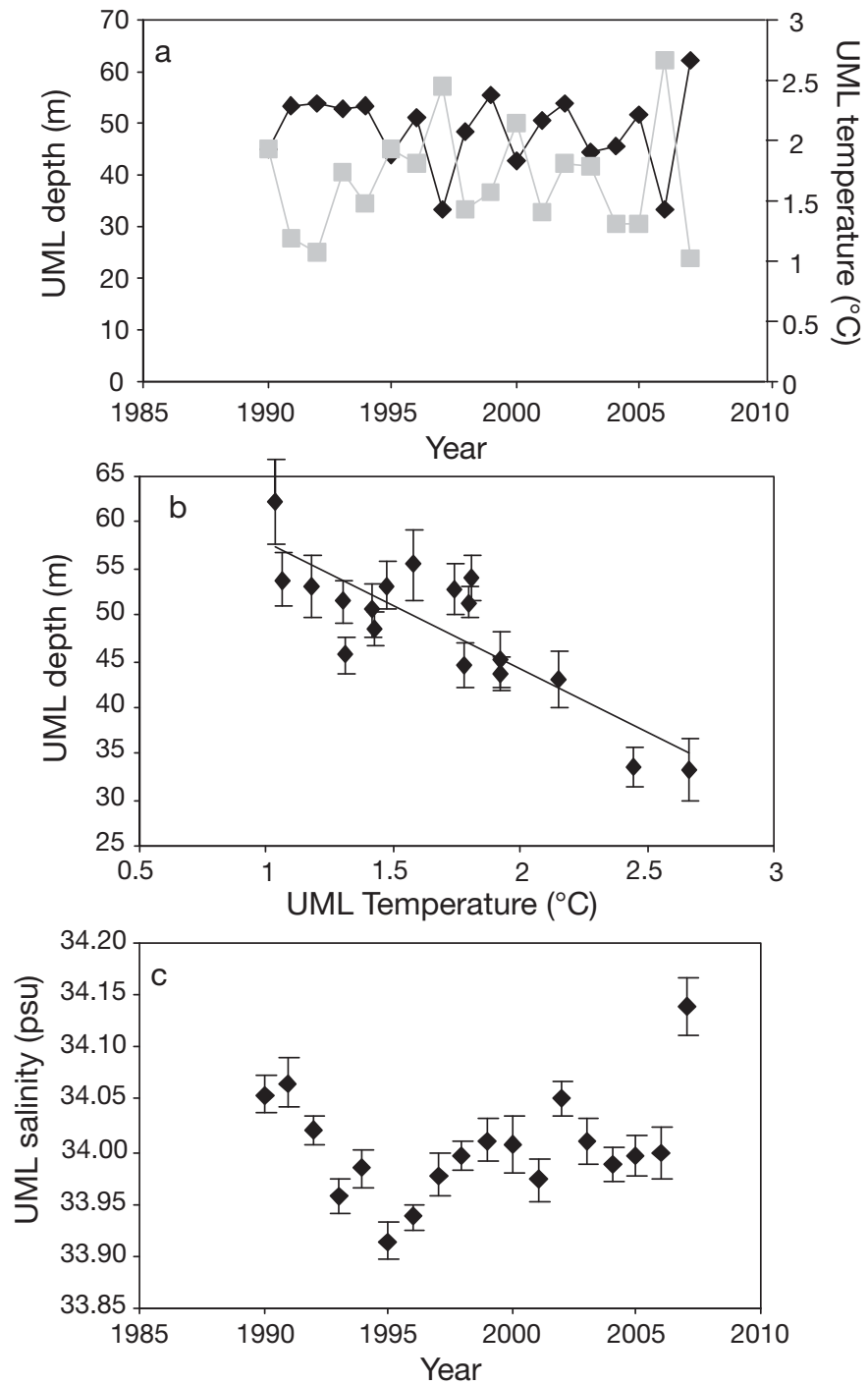

Fig. 4. Characteristics of the upper mixed layer (UML) around Elephant Island from 1990 to 2007. (a) Time series of UML depth $(\diamond)$ and temperature $(\square)$; (b) relationship between depth and temperature of the UML; (c) time series of UML salinity (psu). Values are mean $\pm \mathrm{SE}$

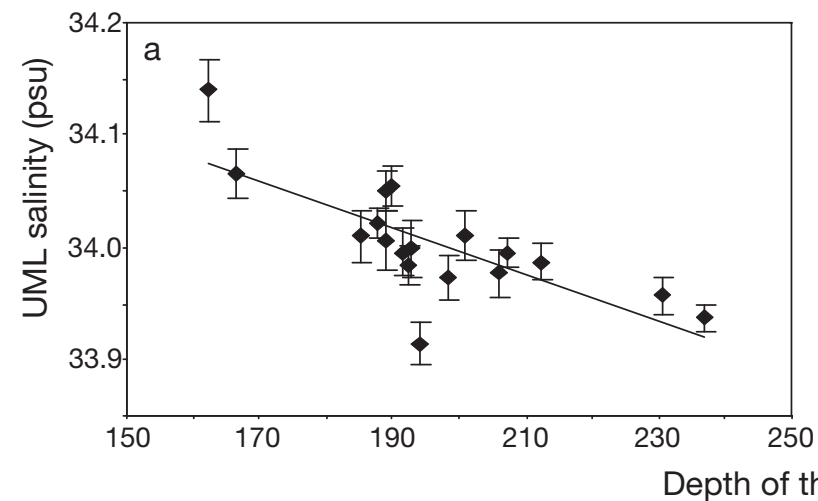

during negative phases of the SOI (i.e. El Niño periods) as well. Sea ice extent, lagged by $1 \mathrm{yr}$, was not correlated with UML temperature, UML salinity, or chl a (not shown), suggesting that within the US AMLR area, ice melt is not directly related to productivity the following summer.

Both integrated and mean chl a concentration for the UML were low when the SOI was negative and variable during other years. A significant correlation between the magnitude of SOI and mean chl a concentration $(\mathrm{r}=0.53 ; \mathrm{p}<0.05)$ was found for 3 anomalous years, i.e. the 2 high chl a years $(1995,2006)$ and a low chl a year (2001), suggesting that other factors remained important in affecting chl a biomass in the EI region.

UML nutrient concentrations (nitrate and silicate) also varied over the 18 -yr time series and were, on average, higher when the SOI index was low (Fig. $7 \mathrm{c}, \mathrm{d})$. The minimum nitrate $(\sim 25 \mu \mathrm{M})$ and silicate $(\sim 47 \mu \mathrm{M})$ concentrations occurred during 1997. Maximal concentrations of nitrate and silicate exceeded 31 and $75 \mu \mathrm{M}$, respectively. It is unlikely that the temporal variability in nutrient concentrations was simply the result of variability in assimilation during high or low chl a years. A drawdown of roughly $1 \mu \mathrm{mol}$ nitrate $\mathrm{l}^{-1}$ should reflect a change in chl a concentration of about $1.5 \mathrm{mg} \mathrm{m}^{-3}$, suggesting that $\mathrm{chl}$ a concentrations could have varied by more than $5 \mathrm{mg} \mathrm{m}^{-3}$ if nutrients were limiting primary production in this region. Therefore, drawdown of nutrients could bias associations with the SOI. However, the higher concentration of both silicate and nitrate with low SOI is not simply the result of lower uptake rates by phytoplankton. Partial correlation between the SOI and nutrients, controlling for chl a concentration, was marginally significant for silicate $(r=-0.6 ; p<0.07)$ and uncorrelated for nitrate. However, the signs were negative in both cases, suggesting that when the SOI index is negative, nutrient concentrations are likely to be high. The nutrient con-

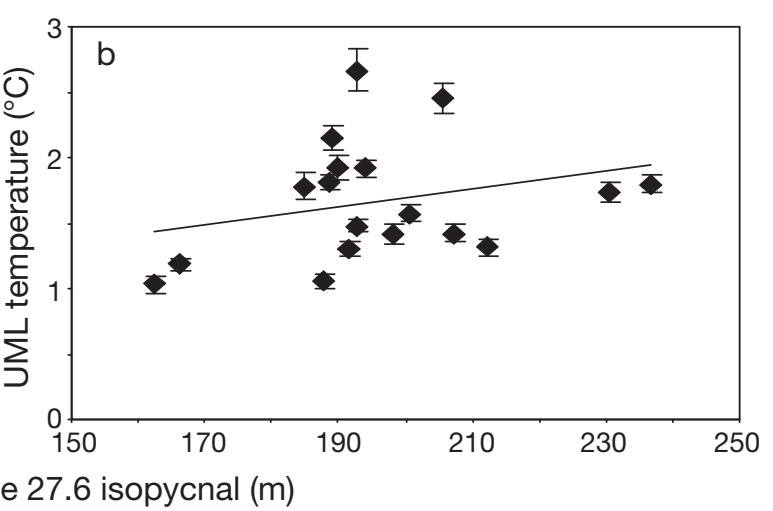

Fig. 5. Relationship between mean depth of the $27.6 \sigma_{t}$ isopycnal and (a) mean ( \pm SE) salinity (psu) of the upper mixed layer (UML) and (b) mean $\left( \pm \mathrm{SE}\right.$ ) temperature $\left({ }^{\circ} \mathrm{C}\right)$ in the UML around Elephant Island from 1990 to 2007 . Trend line in (a) and (b) was fit to inverse variance weighted ordinary least squares regression, and is significant $\left(r^{2}=0.53 ; \mathrm{p}<0.001\right)$ for the salinity/depth relationship in $(\mathrm{a})$ 

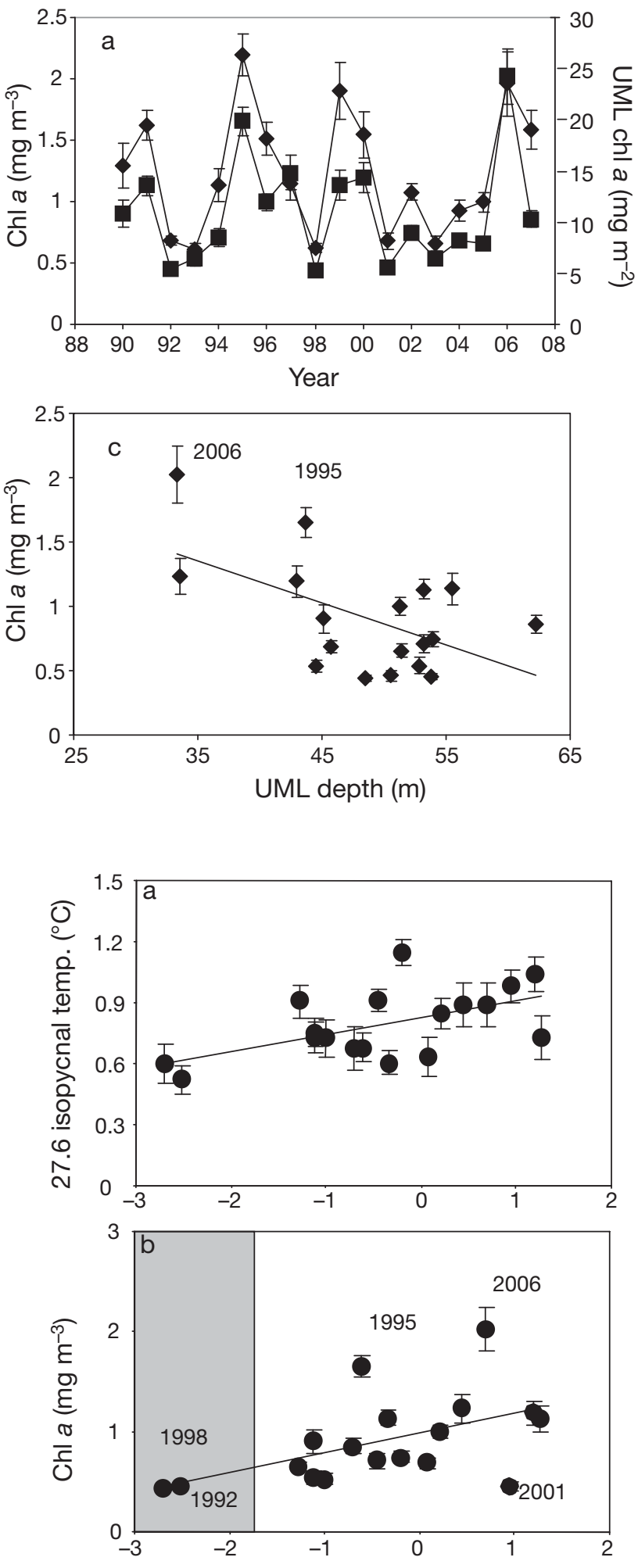

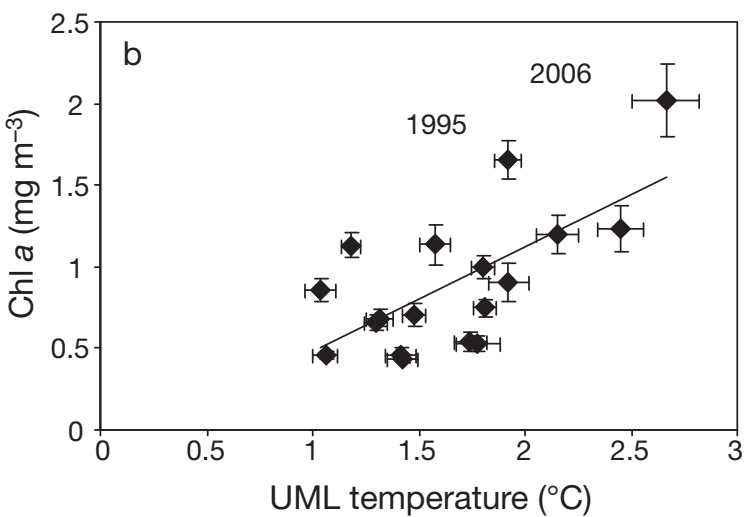

Fig. 6. Relationships between (a) upper mixed layer (UML) chlorophyll a (chl a) concentration $\left(\mathrm{mg} \mathrm{m}^{-3}, \mathbf{\square}\right)$ and UML integrated $\mathrm{chl}$ a biomass $\left(\mathrm{mg} \mathrm{m}^{-2}, \bullet\right)$ around Elephant Island from 1990 to 2007, (b) chl a concentration $\left(\mathrm{mg} \mathrm{m} \mathrm{m}^{-3}\right)$ and temperature, and (c) chl a concentration $\left(\mathrm{mg} \mathrm{m}^{-3}\right)$ and depth of the UML. Values are means $( \pm \mathrm{SE})$
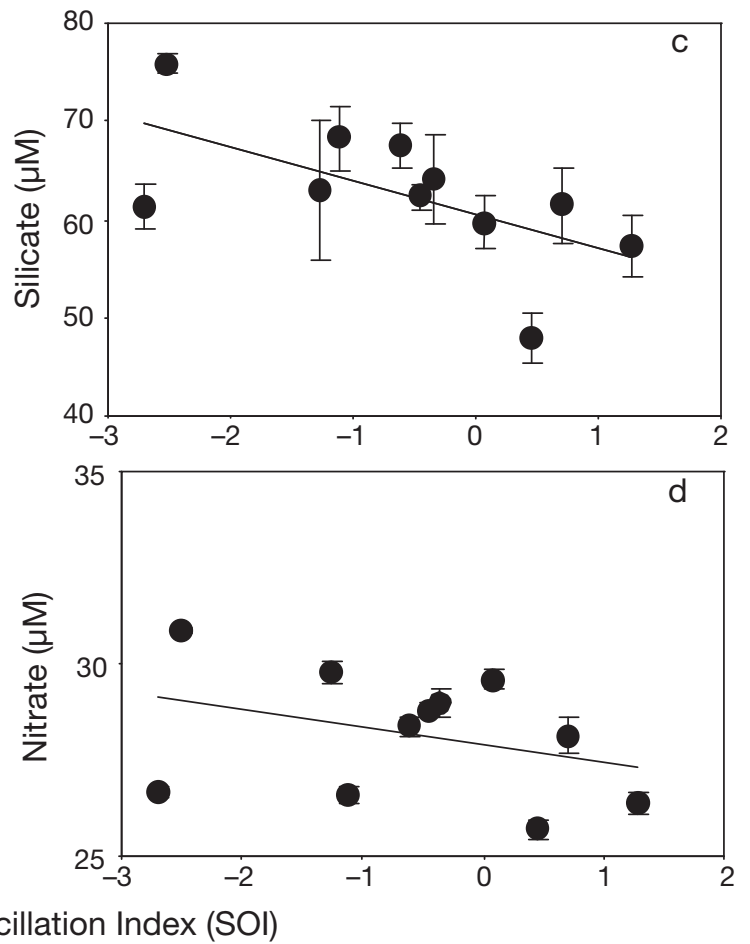

Fig. 7. Mean upper water column characteristics around Elephant Island from 1990 to 2007 in relation to the SOI (Southern Ocean Oscillation Index). Relationships between the SOI and mean $\left( \pm \mathrm{SE}\right.$ ) (a) temperature along the $27.6 \sigma_{\mathrm{t}}$ isopycnal, (b) chl a concentration in the upper mixed layer (UML), (c) silicate concentrations in the UML, (d) nitrate concentrations in the UML. Inverse-variance weighted ordinary least squares regression was used to examine trends and is fit to the means to account for unequal sampling within and among years. Highlighted area in (b) shows the El Niño-Southern Oscillation (ENSO) years, defined by a low SOI 
centrations in the UML were uncorrelated with temperature or salinity at the $27.6 \sigma_{\mathrm{t}}$ isopycnal $(\mathrm{r}=-0.26$ to -0.58 , respectively; $\mathrm{p}>0.05$ ), although the consistent negative sign is indicative of a decline in these nutrients when the influence of UCDW may be greater (presence of warm high salinity water at the 27.6 isopycnal). Partial correlation, accounting for the effect of chl a concentration, did not change this pattern. Furthermore, these UML nutrients were either uncorrelated (silicate; $\mathrm{r}=0.07$; $\mathrm{p}>0.1$ ) or positively correlated with UML salinity (nitrate; $r=0.33$; $\mathrm{p}<0.05$ ). Taken together, these data suggest that nutrient concentrations are higher (albeit slightly) when the SOI index is negative. At these times, there is also an increased presence of WSSW in the UML (Fig. 5), which corresponds with the lowest phytoplankton biomass (Fig. 7b).

\section{DISCUSSION}

The circulation around the South Shetland Islands region off the Antarctic Peninsula is complicated and results in a complex mixing of water masses (HolmHansen et al. 1997). Cold, saline shelf water from the Weddell Sea flows into the Bransfield Strait around the tip of the Antarctic Peninsula, and some flows north before turning west around Elephant Island (Whitworth et al. 1994). These cold, salty waters mix with the ACC, which is comprised of warm and fresh Antarctic Surface Water (AASW), the very cool Winter Water remnant that is present in the ACC at depths between 70 and $100 \mathrm{~m}$ and, finally, warm and saline UCDW (Holm-Hansen \& Hewes 2004, Hewes et al. 2008). The variability in the amount of horizontal mixing (driven by atmospheric forcing) between the ACC-like and Weddell-like waters generates much of the pattern in temperature and salinity observed in this study. Despite the complexity, 18 yr of hydrographic data collected around the EI area show significant correlations between subsurface water properties (temperature, salinity, and the depth of the $27.6 \sigma_{t}$ isopycnal), indicative of UCDW at the continental margin, and the SOI that defines the principal atmospheric teleconnection between the high and low latitudes (Turner 2004, White et al. 2004). These results differ from previous multi-year summaries of this region (Amos 2001, Williams et al. 2006) and may indicate that either recent changes (since 1999; Fig. 2) in the dynamics of the system have occurred or that the time-series of oceanographic, chemical and biological factors are now long enough to begin to discern patterns in the interannual variability of this system.

The pattern in the UCDW water properties we observed showed considerable interannual variability and potentially longer-term, near decadal variability given the results from polynomial regression (Figs. 2 \& 3). Not surprisingly, these results suggest that a variety of processes are responsible for water properties in this region and could reflect the low correlations observed for some of our analyses. Our observations differ from long-term secular changes in temperature discerned for deeper waters (Gille 2002) associated with long term ocean warming. Our results better reflect the types of interannual variability described by Sprintall (2003), who showed that variability in the transport of the ACC in the Drake Passage is associated with the zonal wind-stress and wind-stress curl in the southeastern Pacific. Increased transport will increase upwelling (Pollard et al. 2002, 2006, Meredith et al. 2004), which should also increase the extent of UCDW along the South Shetland Islands.

Although a number of studies have shown that sea ice variability is critical in controlling ecosystem dynamics (e.g. Loeb et al. 1997, Stammerjohn \& Smith 1997), no relationship was found between the extent of sea ice lagged one year and any water properties during this 18-yr time series. As the El Niño phenomenon is correlated with changes in sea ice over long time periods (Turner 2004), our results may reflect either (1) the overall importance of the local oceanatmosphere dynamics (local heat flux) embedded within broader basin scale forcing (affecting Weddell outflow; Venegas \& Drinkwater 2001), or (2) a change in the dynamics of the sea ice-El Niño relationship (Zwally et al. 2002). The first possibility is supported by the positive relationship between UML temperature and UML chl a concentration. This possibility is also supported by the fact that the UML temperature was likely influenced by the local heat flux, the strength and frequency of storms, and the transport and horizontal mixing between the ACC and the WSSW that together determine the density of the water in the surface layer affecting the depth of the UML. It is known that broad scale atmospheric patterns affect the prevailing direction of the winds and that winds coming off the continent will result in a strong negative heat flux, while winds from more northerly directions are warmer and will tend toward a less negative heat flux, resulting in a higher heat content and potentially a more stratified water column. The increased stratification leads to higher phytoplankton biomass within the UML. The second possibility is supported by recent data from Liu et al. (2002) and Meredith \& King (2005). They show that surface waters of the Bellingshausen Sea (upstream of the WAP) are warming and becoming more saline during a period of sea ice decline that appears to be driving the increase of atmospheric temperatures (Turner et al. 2005) of the Antarctic Peninsula. As such, the lack of a relationship between sea 
ice extent, water column properties and phytoplankton biomass could result from non-local responses to larger scale climate variability.

The relationship between the SOI and subsurface water properties strongly suggests that this forcing is critical to the physical dynamics in the EI area. Regardless of the weaker evidence for long-term low frequency variability in the data (Figs. $2 \& 3$ ), we found a correlation between the SOI and our index of UCDW extent indicative of event scale climate processes (Fig. 7a). Since temperature is positively and salinity is negatively correlated with the depth of $27.6 \sigma_{t}$ isopycnal, it might suggest that upward transport of nutrients and trace metals associated with UCDW would occur during La Niña conditions, resulting in higher phytoplankton biomass during summer (Prézelin et al. 2000, 2004). Yet, if this were the mechanism here, then there should be a relationship between chl a concentration and the depth, temperature, or salinity of the $27.6 \sigma_{t}$ isopycnal; however, no correlation was found.

Processes controlling inter-annual variability in phytoplankton biomass in the EI region appear to be different compared to southwest along the WAP (Prézelin et al. 2000, 2004). Along the WAP, phytoplankton productivity may be influenced by seasonal ice melt and upwelling of UCDW within canyons. However, the influence of UCDW extent, as represented by water temperature at the $27.6 \sigma_{\mathrm{t}}$ isopycnal, was not correlated with chl a concentrations in the EI area. Our results show that variability in UML temperature best explains the interannual variability in chl a concentration in the EI region by modifying the UML depth. The relationship between phytoplankton biomass and the SOI is characteristic of a threshold 'critical depth' effect, with a low SOI coupled to low phytoplankton biomass during these periods. We hypothesize that the increased UML depth results from lower UML temperatures and increased influence of WSSW in the area. The deepening of the UML results in a decline in chl a production during El Niño periods. This is also supported by the low integrated chl a biomass associated with periods of deeper UML. Once some threshold (critical depth) level is reached, photosynthesis is very much reduced, resulting in the consistently low chl a concentrations that correspond with negative SOI values. Further, given the trend of increasing nutrients in the UML during El Niño periods, it is more likely that increased nutrients are transported into this area with cooler waters associated with the Weddell Sea.

Macronutrients do not limit phytoplankton biomass in the Southern Ocean south of the Polar Front (HolmHansen 1985, Pollard et al. 2002, 2006), but they are informative as tracers of water sources in the EI area (Hewes et al. 2008). In contrast, iron limits phytoplank- ton biomass in much of the pelagic Southern Ocean (de Baar et al. 1995), and at the most offshore stations within the EI area (Helbling et al. 1991, Holm-Hansen and Hewes 2004, Hopkinson et al. 2007). Locally, iron is highly correlated with nitrate and silicate (Hewes et al. 2008) and is associated with a Weddell Sea shelfwater source (Sañudo-Wilhelmy et al. 2002). Given the fact that both silicate and nitrate concentrations were high when the SOI was low, iron was probably also elevated in the EI area during El Niño. Therefore, under this scenario it is unlikely that macronutrient or trace element concentrations limit productivity during El Niño conditions. We hypothesize that the extent of UCDW in this area is moderated by enhanced outflow of cold, saline, macronutrient and trace metal rich WSSW during El Niño, which leads to deeper UML depths, negatively affecting phytoplankton productivity.

UML temperature, which is slightly cooler when the SOI is negative (indicative of El Niño events) and during periods of greater Weddell influence, may slightly affect phytoplankton growth rates (Neori \& HolmHansen 1982). Given the difference in mean UML temperatures of about $1.5^{\circ} \mathrm{C}$ among years, phytoplankton growth rates might vary by about $12 \%$ (assuming light-saturated growth). However, the decline in temperature has a more dramatic impact on UML depth. This same range of temperatures influences surface water density, increasing it by about $0.1 \sigma_{t}$ over the range of mean UML temperatures. Moreover, this change in temperature is associated with a change in UML depth of about $30 \mathrm{~m}$ (Fig. 5). Several studies have examined the importance of the UML depth for phytoplankton productivity in the Southern Ocean (e.g. Mitchell \& Holm-Hansen 1991, Nelson \& Smith 1991, Sakshaug et al. 1991). In general, when the surface mixed layer depth exceeds $\sim 50 \mathrm{~m}$ in Southern Ocean waters, phytoplankton biomass remains low and bloom occurrence is less likely. The impact of this deepening is clearly evident when integrated chl a biomass and mean UML concentration are compared. There is more biomass associated with the shallow UML than with the deep UML, indicating that production declines when the UML is deep, likely the result of a decline in the mean light level encountered by phytoplankton at these times and locations.

During El Niño conditions (negative SOI), the UML depth was deeper than $50 \mathrm{~m}$ and phytoplankton blooms did not occur. However, the low chl a concentration in 2001 was associated with a moderately $(\sim 50 \mathrm{~m})$ deep UML and a higher SOI. Further, the second highest chl a values (1995) occurred at an elevated SOI value, but were associated with a shallower UML (43 m) and a very low mean salinity ( 33.9). Therefore, while additional factors are still important in determin- 
ing the magnitude of blooms, the results indicate that deepening of the UML during El Niño is a major factor in this region that results in low chl a biomass. Given that the UML depths found during El Niño are still within the range of UML depths during some non-El Niño low productivity years, one can speculate on other processes (cloud variability, cumulative incident PAR, net heat flux and mixing) that introduce additional variability in other years.

The processes responsible for the long term low frequency variability we captured in our dataset remain unresolved. Both the averaged data (Fig. 2a,b) and time series contour plots (Fig. 3) show similar variability, suggesting that the period from the mid 1990s to early 2000s was a period of increased influence of UCDW. This corresponds to the period when UML salinities were very low (Fig. 4c). Between the 1980s and 1990s, the Pacific-South American Mode and the SAM were in phase, and atmospheric teleconnections between low latitudes and the Antarctic, especially the Antarctic Peninsula area, were enhanced by height and pressure anomalies in the South Pacific (Fogt \& Bromwich 2006). This was associated with a temporal shift in the strength of the zonally averaged winds from summer to autumn, providing a link to the increased warm periods observed during the 1990s. Likewise, during this same period, considerable variability in the strength of the ACC was observed (Meredith et al. 2004). Weddell Sea circulation might also significantly impact the position and strength of the eastward flowing $\mathrm{ACC}$ as indicated through ocean circulation modeling (Hellmer et al. 2005). Simulations for the western Weddell Sea and adjacent basins during the mid-1990s period show warming that corresponded with enhanced UCDW presence in the EI region. Thus, there is a potential link between the local responses found in our data and broad scale factors that affect decadal scale variability.

There are several sources of variability that we have not investigated in the present study but which will be important to consider in the future. There are few data on the potential for top-down control of phytoplankton biomass over this time period. The US AMLR program collected data on the abundance and distribution of zooplankton taxa captured in nets at all AMLR stations. However, the net mesh $(500 \mu \mathrm{m})$ was rather large, allowing most zooplankton smaller than $750 \mu \mathrm{m}$ to escape. Thus, small microplankton that comprise the vast majority of the consumers of phytoplankton were not sampled. Coupled with Antarctic krill and salps, these taxa might exert considerable top-down control on phytoplankton biomass. Future studies will need to parameterize this source of uncertainty to better resolve whether some of the low correlations could result from top-down effects.
Although few long-term hydrographic data sets exist for the Southern Ocean ecosystem, we have amassed sufficient data to begin resolving event scale and multi-year patterns in productivity in the EI region of the South Shetland Islands. This study provides a cohesive framework linking atmospheric teleconnections to oceanographic processes that directly impact the primary productivity of the EI area. Specifically, we show that ENSO events are directly related to the influence of UCDW and Weddell waters in this area and that, when Weddell waters are present, phytoplankton blooms are less likely to occur because of a deepened UML.

Elucidating the mechanisms responsible for the productivity of the EI area including the South Shetland Islands is important from the traditional biological oceanographic focus (carbon budgets and sequestration), but also because this area is a critical spawning and nursery area for Antarctic krill (Loeb et al. 1997). The Southern Ocean krill population has varied greatly over the last $75 \mathrm{yr}$ (Atkinson et al. 2004), but may have declined by $80 \%$ to the present levels (Atkinson et al. 2004), in part owing to changes in ocean-atmospheric interactions (sea ice) and changes in productivity (Meredith \& King 2005). Future climate scenarios indicate an increased influence of the WSSW outflow in this area (Hellmer et al. 2005, Conil \& Menendez 2006). If this scenario is correct, then we might predict decreased local primary production as observed during El Niño periods. Alternatively, longterm increases of surface temperatures with climate change might also lower the water density of the nutrient enhanced WSSW, resulting in increased local blooms. Thus, there is a great need to understand and model the influence of atmospheric teleconnections on the Weddell Sea circulation and its interaction with the $\mathrm{ACC}$ in the EI region.

Acknowledgements. This work was supported by the US AMLR program, administered by the Antarctic Ecosystem Research Division at NOAA's Southwest Fisheries Research Center, La Jolla, California, funded in part by the National Oceanic and Atmospheric Administration, U.S. Department of Commerce under a series of continuing grants to O.H.-H., most recently NA17RJ1231. We thank all the researchers who helped collect these data over the last $18 \mathrm{yr}$. We thank V. Loeb and S. McClatchie who provided helpful comments on different versions of this manuscript.

\section{LITERATURE CITED}

Amos AF (2001) A decade of oceanographic variability in summertime near Elephant Island, Antarctica. J Geophys Res 106:22401-22423

Atkinson A, Siegel V, Pakhomov E, Rothery P (2004) Longterm decline in krill stock and increase in salps within the Southern Ocean. Nature 432:100-103

Atlas EL, Gordon LI, Hager SW, Park PK (1971) A practical 
manual for the use of the Technicon Autoanalyzer in seawater nutrient analyses: revised. Technical Report 71-22. Oregon State University, Department of Oceanography, Corvallis, OR

Conil S, Menendez CG (2006) Climate fluctuation of the Weddell Sea and its surroundings in a transient climate change scenario. Clim Dyn 27:83-99

de Baar HJW, de Jong JTM, Bakker DCE, Loscher BM, Veth C, Bathmann U, Smetacek V (1995) Importance of iron for plankton blooms and carbon dioxide drawdown in the Southern Ocean. Nature 373:412-415

Fogt RL, Bromwich DH (2006) Decadal variability of the ENSO teleconnection to the high-latitude South Pacific governed by coupling with the Southern Annular Mode. J Clim 19:979-997

Gille ST (2002) Warming of the Southern Ocean since the 1950s. Science 295:1275-1277

Helbling EW, Villafañe V, Holm-Hansen O (1991) Effect of Fe on productivity and size distribution of Antarctic phytoplankton. Limnol Oceanogr 36:1879-1885

> Hellmer HH, Schodlok MP, Wenzel M, Schroter JG (2005) On the influence of adequate Weddell Sea characteristics in a large-scale global ocean circulation model. Ocean Dyn 55:88-99

- Hewes CD, Reiss CS, Kahru M, Mitchell BG, Holm-Hansen O (2008) Control of phytoplankton biomass by dilution and mixed layer depth in the western Weddell-Scotia Confluence. Mar Ecol Prog Ser 366:15-29

> Hewitt RP, Demer DA, Emery JH (2003) An eight-year cycle in krill biomass density inferred from acoustic surveys conducted in the vicinity of the South Shetland Island during the austral summers of 1991/92 through 2001/02. Aquat Living Resour 16:205-213

Hiscock MA, Marra J, Smith WO, Goericke R and others (2003) Primary productivity and its regulation in the Pacific sector of the Southern Ocean. Deep-Sea Res II 50: 533-558

Holm-Hansen O (1985) Nutrient cycles in Antarctic marine ecosystems. In: Siegfried WR, Condy PR, Laws RM (eds) Antarctic nutrient cycles and food webs. Springer-Verlag, Heidelberg, p 6-10

Holm-Hansen O, Hewes CD (2004) Deep chlorophyll-a maxima (DCMs) in Antarctic waters. I. Relationships between DCMs and the physical, chemical, and optical conditions in the upper water column. Polar Biol 27:699-710

Holm-Hansen O, Riemann B (1978) Chlorophyll a determination: improvements in methodology. Oikos 30:438-447

Holm-Hansen O, Lorenzen CJ, Holmes RW, Strickland JDH (1965) Fluorometric determination of chlorophyll. J Cons Int Explor Mer 30:3-15

Holm-Hansen O, Hewes CD, Villafañe VE, Helbling EW, Silva N, Amos A (1997) Phytoplankton biomass and distribution in relation to water masses around Elephant Island, Antarctica. Polar Biol 18:145-153

Hopkinson BM, Mitchell BG, Reynolds RA, Wang H and others (2007) Iron limitation across chlorophyll gradients in the southern Drake Passage: phytoplankton responses to iron addition and photosynthetic indicators of iron stress. Limnol Oceanogr 52:2540-2554

Jeffrey SW, Humphrey GF (1975) New spectrophotometric equations for determining chlorophylls $\mathrm{a}, \mathrm{b}, \mathrm{c}_{1}$ and $\mathrm{c}_{2}$ in higher plants, algae and natural phytoplankton. Biochem Physiol Pflanz 167:191-194

Klinck JM (1998) Heat and salt changes on the continental shelf west of the Antarctic Peninsula between January 1993 and January 1994. J Geophys Res 103:7617-7636

Kwok R, Comiso JC (2002) Southern Ocean climate and sea ice anomalies associated with the Southern Oscillation. J Clim 15:487-496

Lipsky J (2007) AMLR 2006/2007 Field Season Report: Objectives, accomplishments and tentative conclusions. NOAA-TM-NMFS-SWFSC-415. NMFS Southwest Fisheries Science Center, La Jolla, CA

Liu J, Martinson DG, Yuan X, Rind D, Liu JP, Yuan XJ (2002) Evaluating Antarctic sea ice variability and its teleconnections in global climate models. Int J Climatol 22:885-900

Loeb V, Siegel V, Holm-Hansen O, Hewitt R, Fraser WR, Trivelpiece WZ, Trivelpiece SG (1997) Effects of sea-ice extent and krill or salp dominance on the Antarctic food web. Nature 387:897-900

Loeb V, Hofmann EE, Klinck J, Holm-Hansen O, White W (2008) ENSO and Variability of the Antarctic Peninsula Pelagic Marine Ecosystem. Ant Sci doi:10.1017/S0954102008001636

Meredith MP, King JC (2005) Rapid climate change in the ocean west of the Antarctic Peninsula during the second half of the 20th century. Geophys Res Lett 32:9604-9607 doi:10.1029/2005GL024042

Meredith MP, Woodworth PL, Hughes CW, Stepanov J (2004) Changes in the ocean transport through Drake Passage during the $1980 \mathrm{~s}$ and $1990 \mathrm{~s}$, forced by changes in the Southern Annular Mode. Geophys Res Lett 31:L21305, doi:10.1029/2004GL021169

$>$ Mitchell BG, Holm-Hansen O (1991) Observations and modeling of the Antarctic phytoplankton crop in relation to mixing depth. Deep-Sea Res A 38:981-1007

Nelson DM, Smith WO (1991) Sverdrup revisited: critical depths, maximum chlorophyll levels, and the control of Southern Ocean productivity by the irradiance-mixing regime. Limnol Oceanogr 36:1650-1661

Neori A, Holm-Hansen O (1982) Effect of temperature on rate of photosynthesis in Antarctic phytoplankton. Polar Biol $1: 33-38$

Orsi AH, Whitworth T III, Nowlin WD (1995) On the meridional extent and fronts of the Antarctic Circumpolar Current. Deep-Sea Res 42:641-673

Orsi AH, Whitworth T, Sparrow M, Chapman P, Gould J (2005) Hydrographic atlas of the World Ocean Circulation Experiment (WOCE). Vol 1: Southern Ocean. WOCE International Project Office, Southampton

Pollard RT, Lucas MI, Read JF (2002) Physical controls on biogeochemical zonation in the Southern Ocean. Deep-Sea Res II 49:3289-3305

Pollard RT, Tréguer P, Read JF (2006) Quantifying nutrient supply to the Southern Ocean. J Geophys Res 111: 10001-10030

Prézelin BB, Hofmann EE, Mengelt C, Klinck JM (2000) The linkage between Upper Circumpolar Deep Water (UCDW) and phytoplankton assemblages on the west Antarctic Peninsula continental shelf. J Mar Res 58:165-202

> Prézelin BB, Hofmann EE, Moline M, Klinck JM (2004) Physical forcing of phytoplankton community structure and primary production in continental shelf waters of the Western Antarctic Peninsula. J Mar Res 62:419-460

- Sachs JP, Anderson RF (2005) Increased productivity in the subantarctic ocean during Heinrich Events. Nature 434: $1118-1121$

Sakshaug E, Slagstad D, Holm-Hansen O (1991) Factors controlling the development of phytoplankton blooms in the Antarctic Ocean - a mathematical model. Mar Chem 35: $259-271$

Sañudo-Wilhelmy SA, Olsen KA, Scelfo JM, Foster TD, Flegal AR (2002) Trace metal distributions off the Antarctic Peninsula in the Weddell Sea. Mar Chem 77:157-170 
Shevenell AE, Kennett JP (2004) Paleoceanographic change during the Middle Miocene climate revolution: an Antarctic stable isotope perspective. Geophys Monogr Ser 151. American Geophysical Union, Washington DC, p 235-252

Sievers HA, Nowlin WD (1984) The stratification and water masses at Drake Passage. J Geophys Res 89:10489-10514

Sprintall J (2003) Seasonal to interannual upper-ocean variability in the Drake Passage. J Mar Res 61:27-57

Stammerjohn SE, Smith RC (1997) Opposing Southern Ocean climate patterns as revealed by trends in regional sea ice coverage. Clim Change 37:617-639

Stammerjohn SE, Drinkwater MR, Smith RC, Liu X (2003) Iceatmosphere interactions during sea-ice advance and retreat in the western Antarctic Peninsula region. J Geophys Res 108:3329, doi: 10.1029/2002JC001543

Turner J (2004) The El Niño-southern oscillation and Antarctica. Int J Climatol 24:1-31

- Turner J, Colwell SR, Marshall GJ, Lachlan-Cope TA and others (2005) Antarctic climate change during the last 50 years. Int J Climatol 25:279-294

Tynan CT (1998) Ecological importance of the Southern Boundary of the Antarctic Circumpolar Current. Nature

Editorial responsibility: Alain Vézina,

Dartmouth, Nova Scotia, Canada
392:708-710

Venegas SA, Drinkwater MR (2001) Sea ice, atmosphere and upper ocean variability in the Weddell Sea, Antarctica. J Geophys Res 106:16747-16765

White WB, Annis J (2004) Influence of the Antarctic Circumpolar Wave on El Niño and its multidecadal changes from 1950 to 2001. J Geophys Res 109:C06019.

White WB, Peterson RG (1996) An Antarctic circumpolar wave in surface pressure, wind, temperature and sea-ice extent. Nature 380:699-702

- White WB, Gloersen P, Simmonds I (2004) Tropospheric response in the Antarctic Circumpolar Wave along the Sea Ice Edge around Antarctica. J Clim 17:2765-2779

Whitworth T, Nowlin W, Orsi A, Locarnini R, Smith S (1994) Weddell Sea shelf water in the Bransfield Strait and Weddell Scotia Confluence. Deep-Sea Res 41:629-641

Williams A, Bacon S, Cunningham S (2006) Variability of the Lower Circumpolar Deep Water in Drake Passage 1926-2005. Geophys Res Lett doi:10.1029/2005GL024226

> Zwally HJ, Comiso JC, Parkinson CL, Cavalieri DJ, Gloerson P (2002) Variability in Antarctic sea ice 1979-1998. J Geophys Res 107:3041-3059

Submitted: December 30, 2007; Accepted: November 16, 2008 Proofs received from author(s): February 20, 2009 